\title{
PENERAPAN MANAJEMEN TERPADU BALITA SAKIT (MTBS) PADA KADER POSYANDU DAN MASYARAKAT
}

DOI: https://doi.org/10.33024/jkpm.v4i5.4336

\author{
T. Iskandar Faisal ${ }^{1}$, Nuswatul Khaira ${ }^{2}$, Niswah $^{3}$, Alchalidi $^{4}$, Dewita $^{5}$, \\ Nora Veri ${ }^{6 *}$ \\ 1-3 Jurusan Keperawatan Poltekkes Kemenkes Aceh \\ 4-6 Prodi Kebidanan Langsa Poltekkes Kemenkes Aceh
}

Email Korespondensi: Nora.rahman1983@gmail.com

\begin{abstract}
ABSTRAK
Salah satu langkah dalam pencapaian target Millenium Development Goals/MDG's (goal ke-4) adalah menurunkan kematian anak menjadi 2/3 bagian dari tahun 1990 sampai pada 2020. Dalam mencapai target tersebut, pemerintah salah satunya menerapkan Majemen Terpadu Balita Sakit (MTBS) yaitu merupakan pendekatan keterpaduan dalam tatalaksana balita sakit yang datang berobat ke fasilitas rawat jalan. Saat ini banyak tenaga kesehatan, kader dan masyarakat yang tidak mengetahui secara menyeluruh tentang penerapan MTBS. Tujuan kegiatan pengabdian dilakukan untuk meningkatkan pengetahuan kader dalam menerapkan MTBS. Metode pelaksanaan adalah dengan pemberdayaan kader dalam penerapan MTBS sehingga dapar dilakukan upara preventif dan kuratif pada balita sakit. Hasil kegiatan menunjukkan kegiatan diikuti oleh 100\% sasaran kegiatan dan peserta mampu mengikuti kegiatan sampai akhir.
\end{abstract}

Kata Kunci : Manajemen Terpadu Balita Sakit, Diare, Oralit, Kader Posyandu

\begin{abstract}
One of the steps in achieving the Millennium Development Goals / MDG's target (goal 4) is to reduce child mortality to 2/3 parts from 1990 to 2020. In achieving this target, the government is one of them implementing the Integrated Management of Sick Toddlers (MTBS), which is an integrated approach in management. sick toddlers who come for treatment at outpatient facilities. Currently, many village health workers, and the community do not know thoroughly about the implementation of MTBS. The purpose of this service activity is to increase the knowledge of village health workers in implementing MTBS. The method of implementation is by empowering village health workers in the implementation of MTBS so that preventive and curative measures can be carried out for sick toddlers. The results of the activity showed that the activity was followed by $100 \%$ of the target of the activity and the participants were able to follow the activity until the end.
\end{abstract}

Keywords: Integrated Management of Sick Toddlers, Diarrhea, ORS, village health worker 


\section{PENDAHULUAN}

Salah satu langkah dalam pencapaian target Millenium Development Goals/MDG's (goal ke-4) adalah menurunkan kematian anak menjadi 2/3 bagian dari tahun 1990 sampai pada 2020 (WHO, 2015). Selama ini upaya menurunkan angka tersebut di tingkat pelayanan kesehatan dasar disamping menekankan pencegahan primer melalui upaya-upaya yang bersifat promotif dan preventif telah memanfaatkan upaya pencegahan sekunder termasuk upaya kuratif dan rehabilitatif di unit rawat jalan (Chalid, 2016). Pendekatan program perawatan balita sakit di negara-negara berkembang termasuk Indonesia, yang dipakai selama ini adalah program intervensi secara terpisah untuk masing-masing penyakit. Penanganan yang terpisah seperti ini akan menimbulkan masalah kehilangan peluang dan putus pengobatan pada pasien yang menderita penyakit lain selain penyakit yang dikeluhkan dengan gejala yang sama atau hampir sama (Rohayati et al., 2015).

Mengatasi kelemahan program atau metode intervensi tersebut, World Health Organization (WHO) dan United Nations International Children's Emergency Fund (UNICEF) mengembangkan suatu paket yang memadukan pelayanan terhadap balita sakit dengan cara memadukan intervensi yang terpisah tersebut menjadi satu paket tunggal yang disebut Integrated Management of Childhood Ilness (IMCI) (WHO, 2014). Di Indonesia IMCI dikembangkan menjadi Manajemen Terpadu Balita Sakit (MTBS) yaitu suatu program yang bersifat menyeluruh dalam menangani balita sakit yang datang ke pelayanan kesehatan dasar (Nurmawati \& Erawantini, 2019). MTBS merupakan pendekatan keterpaduan dalam tatalaksana balita sakit yang datang berobat ke fasilitas rawat jalan. Pelayanan kesehatan dasar yang meliputi upaya kuratif terhadap penyakit pneumonia, diare, campak, malaria, infeksi telinga, malnutrisi, dan upaya promotif dan preventif yang meliputi imunisasi, pemberian vitamin $\mathrm{A}$ dan konseling pemberian makan yang bertujuan untuk menurunkan angka kematian bayi dan anak balita serta menekan morbiditas karena penyakit tersebut (Nurlaela et al., 2020; Tisnawati \& Ilda, 2021).

Penerapan MTBS berhubungan dengan kejadian diare pada anak. Target cakupan pelayanan penderita diare Balita yang datang ke sarana kesehatan adalah 20\% dari perkiraan jumlah penderita diare Balita. Tahun 2018 jumlah penderita diare Balita yang dilayani di sarana kesehatan sebanyak 1.637 .708 atau 40,90\% dari perkiraan diare di sarana kesehatan (Kementerian Kesehatan RI, 2019). Penelitian Sample Registration System (SRS) tahun 2014 menunjukkan hasil yang sedikit berbeda dimana penyebab utama kematian anak balita adalah diare (17\%) dan pneumonia (13\%) (Sari, 2017). Hasil Survei Demografi dan Kesehatan Indonesia (SDKI) tahun 2017 menunjukkan AKN sebesar 15 per 1.000 kelahiran hidup, AKB 24 per 1.000 kelahiran hidup, dan AKABA 32 per 1.000 kelahiran hidup (Kementerian Kesehatan RI, 2019)

Survey awal yang dilakukan terhadap 5 (lima) orang bidan di Puskesmas Darul Imarah, 3 (tiga) orang bidan menyatakan pernah mendengar tentang MTBS tetapi tidak pernah mengikuti pelatihan dan tidak pernah menerapkan pada balita. Kegiatan ini bertujuan untuk memberi pengetahuan tentang MTBS sehingga hasil akhir peserta pelatihan dapat menerapkan MTBS pada balita. 


\section{MASALAH}

Permasalahan yang mendasari program pengabdian kepada masyarakat ini adalah kurangnya pengetahuan kader tentang penerapan MTBS. Seharusnya petugas kesehatan dan kader harus dapat mengetahui tentang MTBS dan program-programnya sehingga dapat melakukan deteksi dini permasalahan kesehatan yang terjadi pada balita.

Secara jelas diuraikan pada skema berikut ini :

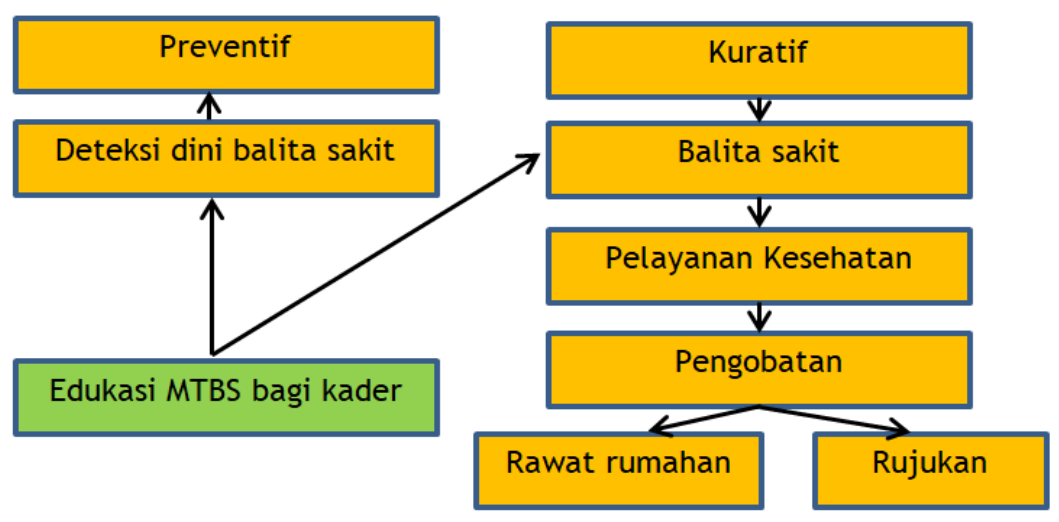

Skema

Kerangka Pemecahan Masalah

Lokasi kegiatan dilakukan di Desa Lambleut Kecamatan Kec. Darul Kamal, Aceh Besar. Peta lokasi PKM tergambar dibawah ini :

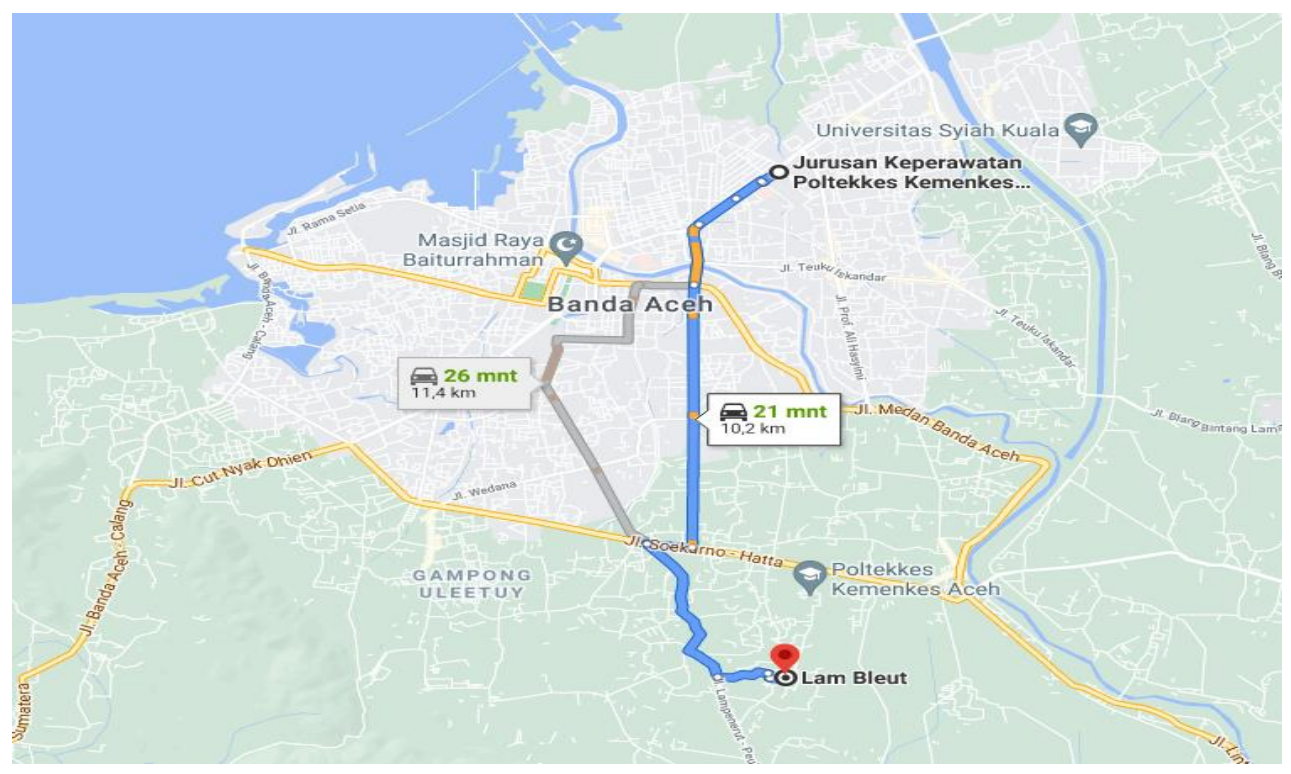

Gambar 2.1. Peta Lokasi Pengabdian 


\section{METODE}

Metode atau bentuk kegiatan yang digunakan adalah program pendidikan masyarakat melalui peningkatan pengetahuan kader Posyandu tentang MTBS. Kegiatan dilakukan melalui tahap-tahap berikut :

a. Tahap Persiapan

Tahap persiapan kegiatan adalah pembuatan SAP, POA, koordinasi dengan kelurahan Gampong Lambleut Kecamatan Darul Kamal, pembuatan leaflet dan media presentasi.

b. Tahap Pelaksanaan

Kegiatan penyuluhan mengenai Pendidikan Kesehatan Tentang Pentingnya MTBS pada balita yaitu :

Tahap Pertama :

1) Pre Test, Penyuluhan tentang MTBS secara umum dan diare secara khusus.

2) Membimbing cara membuat oralit dan obat batuk

3) Post Test dan pembagian leaflet

c. Evaluasi dan Monitoring Kegiatan

1) Melakukan Evaluasi dan Monitoring kegiatan yaitu hasil penyuluhan tentang MTBS pada kader posyandu.

2) Evaluasi sosialisasi/penyuluhan kesehatan dilakukan dengan memberikan soal pre tes dan post tes sebanyak 10 soal. Sebelum dan setelah dilakukan penyuluhan peserta diberikan soal yang sama dengan kriteria penilaian :

a) Baik : Jika jawaban responden benar dengan nilai 76\%-100\% yaitu dengan total score $16-20$

b) Cukup : Jika jawaban responden benar dengan nilai $56 \%-75 \%$ yaitu dengan total score 12 - 14

c) Kurang : Jika jawaban responden benar dengan nilai $0 \%-55 \%$ yaitu dengan total score $0-10$

3) Jika nilai post tes lebih baik dari pada pre test, maka penyuluhan dianggap berhasil dengan baik

\section{HASIL DAN PEMBAHASAN}

Berdasarkan hasil kegiatan pengabdian yang dilakukan pada 11 September s/d 12 Oktober 2020.

a. Penyuluhan kegiatan tentang pencegahan infeksi nosocomial pada keluarga pasien.

1) Evaluasi Struktur
a) Tim Dosen Pengabdian Masyarakat melakukan tugas sesuai rencana
b) Media dan alat untuk penyuluhan tersedia
c) Tersedia tempat yang nyaman untuk peserta yang hadir
d) Mayoritas peserta penyuluhan bersedia mengikuti penyuluhan

2) Evaluasi Proses

a) Pelaksanaan sesuai dengan waktu yang telah direncanakan yaitu

b) diruang gedung serba guna Desa Lambleut 2 sesi penyuluhan dan 
c) demonstrasi, walaupun peserta ada yang beranjak pulang sebelum kegiatan selesai. Sesi pertama pada $08.30 \mathrm{~s} / \mathrm{d}$ 10.15 WIB dan sesi berikutnya jam $10.15 \mathrm{~s} / \mathrm{d} 12.15 \mathrm{WIB}$

d) Selama penyuluhan 90\% (sesi pertama, 12 dari 17 orang dan sesi kedua 14 dari 15 orang) peserta mengikuti penyuluhan dengan tertib, focus, koorperatif dan aktif bertanya. Penyuluh mampu menyampaikan materi dengan metode yang dapat di terima peserta, penyuluh saat memberi materi berjalan mendekati peserta tidak hanya duduk di tempat.

e) Fasilitator mampu memfasilitasi peserta masyarakat wilayah kerja Puskesmas Kec. Darul Kamal yang kuarang aktif untuk bertanya.

3) Evaluasi Hasil

a) $90 \%$ (sesi pertama, 15 dari 17 orang dan sesi kedua 14 dari 15 orang) peserta yang hadir mengikuti kegiatan dari awal sampai akhir kegiatan.

b) $90 \%$ (sesi pertama, 15 dari 17, sesi kedua 13 dari 14 orang) peserta mengatakan senang mengikuti kegiatan ini karena

b. Pembuatan Oralit dapat menambah ilmu tentang diare dan upaya pencegahannya.

1) Evaluasi Struktur

a) Tim Dosen Pengabdian Masyarakat melakukan kegiatan sesuai rencana

b) Media dan alat untuk penyuluhan tersedia

c) Tersedia tempat yang memadai untuk pembuatan oralit

d) Tersedia tempat yang memadai untuk mendemonstrasikan pemakaian masker yang benar

e) Peserta bersedia mengikuti demontrasi.

2) Evaluasi Proses

a) Pelaksanaan sesuai dengan waktu yang telah direncanakan

b) Selama demonstrasi pembuatan oralit peserta mengikuti penyuluhan dengan koorperatif dan aktif.

c) Selama demonstrasi penggunaan masker yang benar peserta mengikuti dengan koorperatif dan aktif.

d) Tim Dosen Pengabdian Masyarakat bersama kader mampu mendemonstrasikan pembuatan oralit dan demonstrasi penggunaan masker yang benar kemudian di praktekkan kembali oleh 3 orang peserta.

e) Fasilitator mampu mendampingi dan memfasilitasi peserta yang melihat dan ikut pembuatan oralit demonstrasi penggunaan masker yang benar.

3) Evaluasi Hasil

a) $100 \%$ keluarga Gampong Lambleut yang hadir mengikuti kegiatan demonstrasi pembuatan oralit.

b) $80 \%$ (sesi pertama, 14 dari 17 orang dan sesi kedua 12 dari 14 orang) keluarga gampong Lambleut yang hadir mengikuti kegiatan demonstrasi pembuatan oralit dan demonstrasi penggunaan masker sampai selesai kegiatan. 5 orang pamit duluan karena pasien yang dibawa tidak sanggup menunggu kegiatan selesai. 
c) Mayoritas keluarga Gampong Lambleut yang hadir mampu mendemonstrasi pembuatan oralit dan penggunaan masker dengan benar

Berdasarkan data SDKI 2017 diperkirakan 763 dari 145 balita meninggal di Indonesia, kematian terbanyak pada balita karena diare, Pneumonia, DBD, Campak dan malaria (BPS, 2018). Salah satu pendekatan yang digunakan untuk meningkatkan kualitas dan akses pelayanan kesehatan bayi dan balita dilakukan melalui Peenerapan Program Manajemen Terpadu Balita Sakit (MTBS). Tujuan dari MTBS adalah untuk menurunkan angka kesakitan dan kematian yang terkait dengan penyebab utama penyakit pada balita melalui peningkatan kualitas pelayanan kesehatan di unit rawat jalan Fasilitas kesehatan dasar (Moelyo et al., 2013).

Kegiatan Penerapan Manajemen Terpadu Balita Sakit (MTBS) di Gampong Lambleut Kecamatan Darul Kamal dilakukan bersama-sama dengan kader Posyandu. Pengabdi memberikan materi mengenai pembuatan oralit dan pemberian jeruk nipis. Kegiatan tersebut masing-masing dihadiri oleh 30 peserta di Gedung Serba Guna Desa Lambleut. Penyampaian materi disampaikan dengan metode ceramah, dilanjutkan dengan diskusi dan tanya jawab dari pelaksanaan kegiatan tersebut pada awalnya diketahui bahwa sebagian besar kader masih belum paham tentang perawatan dasar dirumah.

Pada kegiatan ini pengabdi berikan contoh cara membuat dan memberikan oralit pada anak yang menderita diaree dan pemberian jeruk nipis pada anak yang batuk ringan sesuai dengan usia balita. Pengisian lembar evaluasi (kuisioner Pre dan Post Test) dimaksudkan untuk mengetahui tingkat pemahaman peserta terhadap materi yang telah di sampaikan. Lembar evaluasi berisi 10 soal berupa soal pilihan ganda materi yang telah di sampaikan yaitu Penerapan Manajemen Terpadu Balita Sakit (MTBS).

Berdasarkan pengisian lembarr evaluasi pada saat post tes oleh kader posyandu Lambleut didapatkan hasil bahwa, rata-rata nilai evaluasi berturut-turut sebesar 74 dari 71. Hal tersebut menunjukkan bahwa tingkat pemahaman peserta terhadap materi yang disampaikan telah memenuhi target yang ditetapkan. Pengisian lembar kuisioner dimaksud untuk mengetahui pendapat peserta mengenai kegiatan yang dilaksanakan.

Berdasarkan pesan dan kesan dari salah satu kader posyandu gampong Lambleut menyatakan bahwa kegiatan tersebut bermanfaat, bagi mereka materi yang disampaikan sesuai dengan kebutuhan, mudah dimengerti dan dapat dipraktekkan dalam kehidupan sehari-hari, leaflet yang disampaikan sudah dimengerti, waktu pelaksanaan kegiatan untuk penyampaian materi cukup, namun waktu untuk praktek kurang berhubung kegiatan ini cuma 2 hari tanggal 12 September 2020 kemudian tanggal 12 Oktober 2020. Sesuai dengan teori Penerapan MTBS dengan baik ditingkat dasar (Puskesmas) dapat meningkatkan upaya penurunan kasus secara dini, memperbaiki manajemen penanganan dan pengobatan, promosi, serta peningkatan pengetahuan bagi kader dalam merawat anak sakit di rumah. 


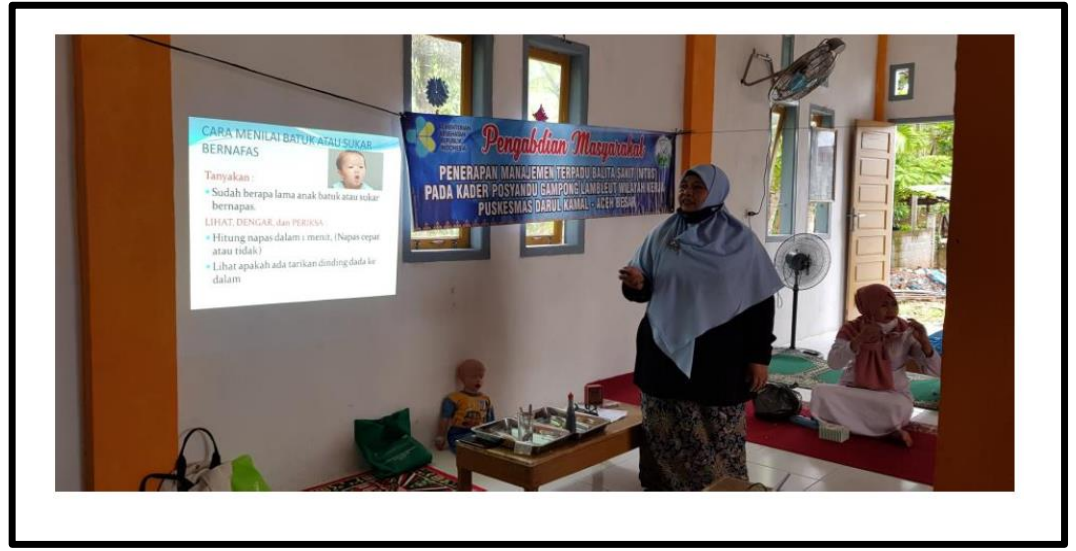

Gambar : Foto Kegiatan PKM

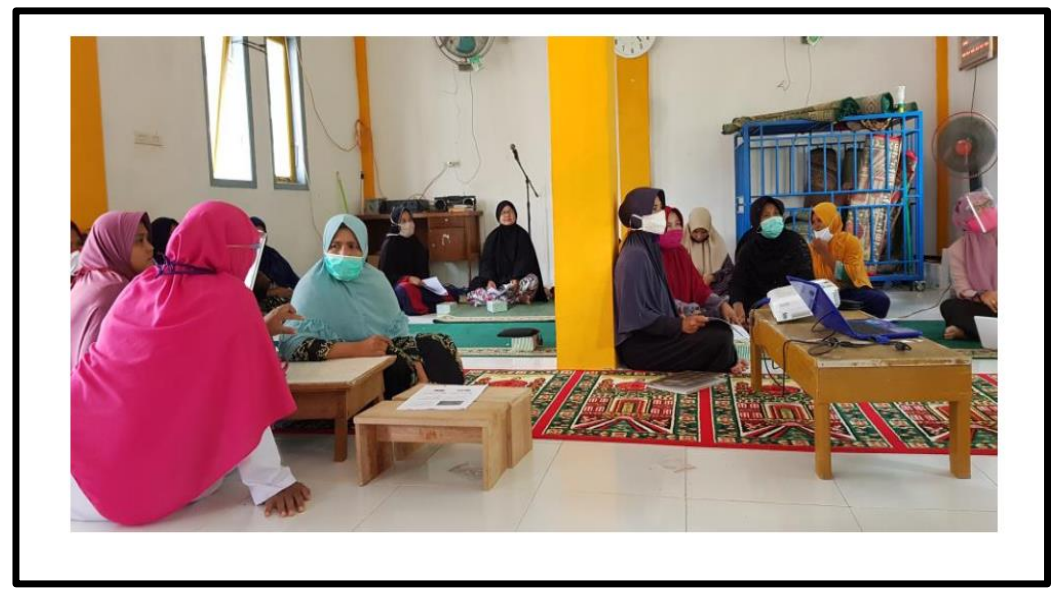

Gambar : Foto Kegiatan PKM

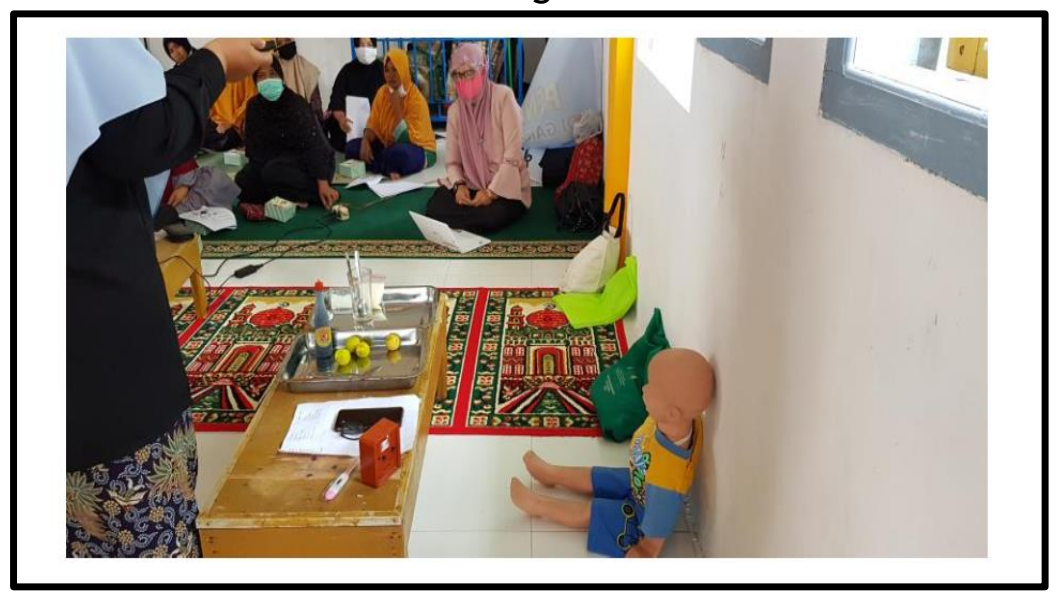

Gambar : Foto Kegiatan PKM 


\section{KESIMPULAN}

Adanya peningkatan pengetahuan kader dan masyarakat setelah dilakukan edukasi tentang MTBS.

\section{DAFTAR PUSTAKA}

BPS. (2018). Survei Demografi dan Kesehatan Indonesia 2017 (Issue November).

Chalid, M. T. (2016). Upaya Menurunkan Angka Kematian Ibu: Peran Petugas Kesehatan. PT.Gakken Health Education Indonesia.

Kementerian Kesehatan RI. (2019). Profil Kesehatan Indonesia 2018. In Kementerian Kesehatan RI (Vol. 1, Issue 1). https: / /doi.org/10.1136/jcp.40.5.591-b

Moelyo, A. G., Widardo, \& Herlambang, G. (2013). Modul Field Lab Edisi Revisi II: Keterampilan Manajemen Terpadu Balita Sakit (MTBS). In Fakultas Kedokteran Universitas Sebelas Maret.

Nurlaela, Darwis, \& Dewi, I. (2020). Hubungan Penerapan Manajemen Terpadu Balita Sakit dengan Kejadian Diare Pada Anak Usia 2-60 Bulan di Puskesmas Paccerakkang Kota Makassar. Ilmiah Kesehatan Diagnosis, 15(3), 233.

Nurmawati, I., \& Erawantini, F. (2019). Kebutuhan Perancangan Sistem Screening Balita Sakit Berdasarkan Klasifikasi dan Penatalasanaan MTBS. Jurnal Kesehatan, 6(3), 83-87. https://doi.org/10.25047/jkes.v6i3.18

Rohayati, Sulastri, \& Purwati. (2015). Analisis Faktor Pelaksanaan Manajemen Terpadu Balita Sakit (MTBS) di puskesmas. Jurnal Keperawatan, 11(1), 112-117.

Sari, Y. R. (2017). Tantangan Implementasi MTBS Di Puskesmas : Literature. Prosiding SNaPP2017 Kesehatan, 1, 172-178.

Tisnawati, \& Ilda, Z. A. (2021). Pengaruh Modul Modifikasi MTBS-M Dalam Deteksi Dini Pnemonia Pada Balita. Menara Ilmu, XV(01), 98-103.

WHO. (2014). Distance Learning Courses: Integrated Management of Childhood Ilness. In World Health Organization. https: / / doi.org/10.4018/978-1-61520-853-1.ch021

WHO. (2015). Health in 2015: from MDGs, Millennium Development Goals to SDGs, Sustainable Development Goals. In World Health Organization (Vol. 1, Issue 1). https: //doi.org/10.1017/S1744552306002023 